\title{
ОПЫТ ОРГАНИЗАЦИИ ОЗДОРОВИТЕЛЬНОЙ СМЕНЫ ДЛЯ ДЕТЕЙ С САХАРНЫМ ДИАБЕТОМ В ВОЛОГОДСКОЙ ОБЛАСТИ
}

\author{
Ж.Г. Безрукова', Е.А. Шилова ${ }^{2}$ \\ 'БУЗ ВО «Вологодская областная детская клиническая больница» \\ ${ }^{2}$ ВООО «Общество больных сахарным диабетом»
}

Вологодская область входит в состав Северо-Западного федерального округа, основана 23 сентября 1937 г. Размеры: с запада на восток - более 700 км, с севера на юг - более 400 км. В составе области - 26 районов и 4 города областного подчинения. Численность населения области на 01.01.2021 г. составляет 1151042 чел., детского населения (0-18 лет) - 269422 чел.

Заболеваемость детей и подростков в возрасте 0-18 лет сахарным диабетом, тип 1, за последние 25 лет выросла значительно. В 1996 г. - 7,48/100 тыс. детского населения, 2005 г. 10,23/100 тыс., в 2015 г. - 29,8/100 тыс., в 2019 г. - 29,6/100 тыс. Аналогично значительно выросла и распространенность данного заболевания: 2011 г. - всего 0-18 лет - 145,0/100 тыс. детского населения (дети 0-15 лет - 118,0/100 тыс.), 2019 г. - всего 0-18 лет - 211/100 тыс. (дети 0-15 лет - 155,8/100 тыс.). В настоящее время на 01.01.2021 г. в области проживают 567 детей, имеющих сахарный диабет 1 типа.

С 2013 г. ежегодно в летнее время организуется оздоровительный отдых таких детей. Смена организуется на базе общего оздоровительного детского лагеря, всегда в очень красивом и уютном месте, недалеко от районного центра. Для удобства наблюдения и контроля за гликемией дети с диабетом находятся в едином отряде, обычно это 20-25 человек. Как правило, это дети старше 8 и младше 16 лет, достаточно самостоятельные, обученные технике инсулинотерапии и самоконтроля. С группой детей постоянно круглосуточно находятся сопровождающие, осуществляющие контроль состояния детей, из расчета 1 сопровождающий на 7-8 человек (на группу 25 человек - 3-4 сопровождающих). В число сопровождающих обязательно входят 1 медицинский работник (обученная медицинская сестра либо врач) и 2-3 волонтера (из числа родителей либо пациентов с СД). Чаще всего продолжительность смены составляет 14 дней. Кроме обычного отдыха со спортивными мероприятиями, конкурсами, экскурсиями, вечерними дискотеками, дети с диабетом проходят обучение в «Школе диабета», учатся брать на себя ответственность за свое заболевание, общаются со сверстниками, имеющими аналогичные проблемы, понимая, что в мире много людей с диабетом. После пребывания на специализированной смене у детей появляется уверенность в жизни и диабете, что всегда отмечается родителями. Очень часто ребята хотят поехать повторно.

Оплата путевок проводится частично за счет средств Фонда социального страхования, частично - за счет благотворительного фонда «Во имя добра», частично (малая часть) - средства родителей. 